\section{THE ROLE OF FAITH BASED ORGANIZATIONS IN DEVELOPMENT: A CRITICAL ANALYSIS}

\section{Md. Didarul Islam*}

\begin{abstract}
There has been a relatively new dimension of development discourse to analyze the role of Faith Based Organizations (FBOs) in global development. In doing so, most of the academic literatures have addressed how FBOs positively contributed to the global development over the years. In contrast, there are some criticisms against the FBOs. This article attempts to elucidate three major criticisms against the FBOs including a. sectarian service provision, b. proselytization and c. terrorist financing. This article finds a mixed result arguing that there are limitations of FBOs in the concerned cases but those limitations do not reduce the significance of the FBOs in global development.
\end{abstract}

Key words: FBOs, development, conversion, proselytization, terrorist financing, sectarian service

\section{Introduction}

There is a shift in the development field regarding the role of religion in development sectors. Previously, the development

\footnotetext{
* Assistant Professor, Department of World Religions and Culture, University of Dhaka, E-mail: didar@du.ac.bd
}

strategists used to ignore religion in development sectors but now, religion has been given attention by development strategists, governments and financial organizations. This shift subsequently denotes the importance of Faith Based Organizations (FBOs) in development discourse. In a sociopolitical atmosphere in the world where it is impossible to ignore religion, Faith Based Organizations have acquired a significant position which was difficult to predict two decades ago (Tomalin, 2013, p. 206). Faith Based Organizations have deeprooted ties with development. Fountain (2015) argued that present day secular development agenda is deeply rooted in the development works of many Faith Based Organizations. Development engagement for Faith Based Organizations is not a new approach. The charitable works of different Churchs like providing humanitarian aid and medicines to the poor are widely known which had a tremendous effect on global development discourse (Denulin and Bano, 2009, p. 84). This kind of service provision is also rooted in Islam (zakat for example. One must spend 2.5 percent of his earnings for charitable work), Hinduism (dyana or charity for example), Buddhism and other faiths. Faith based Organizations can be international as seen through World Vision, Islamic Relief, Christian Aid and can be local like Ramkrishna Mission of Bangladesh, Christian Commission for Development in Bangladesh (CCDB). The creation of the Office of the Faith Based and Community Initiatives by US president George W. Bush was a symbol of formal tie between state and FBOs which encouraged others to come in front to make a bond with FBOs. For instance, the Department of International Development (DFID) of the United Kingdom has established a formal relationship (producing the Faith Partnership Principles for example) with the FBOs aiming to work with FBOs in development sectors (Flanigan, 2010, p. 2). Faith Based 
Organizations are active in many developing countries like Bangladesh, India, Pakistan, African countries and they have been contributing different field of development; i.e., education, relief, child health, poverty reduction, women empowerment, climate change, peace building and many others.

Despite contributing in development sectors, Faith Based Organizations are not beyond criticism as many of them have been accused of patronizing Islamic militants, providing sectarian social services, preaching Wahhabism (an ideology preached by Saudi Arabia) and converting poor to other religions either forcefully or by material benefits. Occhipini (2015) writes that Faith Based Organizations are often seen as suspicious by donors as they spread evangelism and conversion. Though she considers that the religious nature of these suspicious Faith Based Organizations less threatening to secular development organizations at present (Occhipini, 2015, p. 333). But the generalizations of these allegations have increased more confusions and have raised many questions whether all FBOs promote conversion, finance in terrorism and provide sectarian services.

Sometimes, these groups have direct relationship with some political parties. During the post 9/11 era, many Islamic Faith Based Organizations have been brought under investigation by many Western countries like USA, UK, Germany and Norway. Sometimes they have been accused of biasness in service provision. For instance, Flanigan (2010) argued that FBOs may mirror, reinforce, and reproduce societal divisions that are present in the culture in which they operate. This division, in turn accelerates the dynamics of sectarian service provision (Flanigan, 2010, pp. 3-5). This present paper is an attempt to examine the role of Faith Based Organizations
(FBOs) in the development fields with a special attention to the concerning issues like conversion, sectarian service provision, and financing terrorism.

The objectives of this research are varied. This research will seek the answer of the following questions.

a. Do the Faith Based Organizations (evangelical) aim at conversion other than development? Does the service provision nature of the evangelical groups influence poor people to be converted to Christianity?

b. Do the Faith Based Organizations (Islamic FBOs) keep connection with terrorist groups and fund terrorists?

c. Do the Faith Based Organizations (FBOs) provide services only to their respective communities? For instance; do the Christian FBOs provide services to the Christians only?

Attention will also be given on the different typologies to understand the FBOs, but the focus will be given on the allegations against the FBOs. Though a good number of researches have been conducted on the role of Faith Based Organizations, only a few have focused on the allegations against the Faith Based Organizations. This research will accelerate the velocity of the examination of the role of Faith Based Organizations in this regard.

\section{Methodology}

As a social research, this research has been conducted by following qualitative research approach which mainly includes literature review. Qualitative research helps any study to understand any social fact more vividly (Kothari and Garg, 2015). Since the FBOs have been criticized for many times due 
to various reasons, a qualitative study on such issues would enable us to understand the fact for more comprehensive perspectives. Data have been collected from the websites of different organizations, newspapers, journals and books.

\section{Conceptual Framework and Understanding FBOs}

It is difficult to define Faith Based Organizations exclusively. An exclusive definition may be narrow in a sense that might exclude informal organizations, those who are active in development spectrum. There are variations in definitions of FBOs. Though present day literature uses the term FBOs more frequently, there are a few who prefer using RNGOs instead of FBOs. For instance, Bohele (2010) and Julia Berger (2003) used Religious NGOs (Religious Non-Government Organizations) instead of Faith Based Organizations. Berger (2003) defines RNGOs as "Formal organizations whose identity and missions are self-consciously derived from the teachings of one or more religions and spiritual traditions and which operates on a non-profit, independent voluntary basis to promote and realize collectively articulated ideas about the public good at the national or international level" (Berger, 2003, p. 16). They want to see RNGOs more likely as only formal NGOs.

Nathaniel Adams (2015) and World Faith Development Dialogue (WFDD) do not use the term Faith Based Organizations or Faith Based Institutions in an exclusive sense. Instead Adams incorporated the definition of WFDD that includes every kinds of faith Based organizations from Church to NGO are FBOs. Adams (2015) writes: "WFDD's research uses the term FIO (Faith Inspired Organizations) as an inclusive definition that includes any organization engaged in development work, broadly defined, whose mission and vision is inspired or guided by the teachings of a religious tradition or sub-sect and organizations whose history is deeply rooted in such traditions. Within this diverse group, the role of religion in organizational missions or operations also varies: some organizations place religious propagation as central while they engage in social welfare work and other organizations see religious values as simply undergirding more formal relief and development work" (Nathaniel Adams, 2015, p. 52).

Other than defining Faith Based Organizations, G. Clarke (2008), Matthew Clarke (2015), and Occhipini (2015) emphasized on typology of Faith Based Organizations to get a clearer idea. G. Clarke (2008, pp. 25-38) proposed five types of FBOs. These are Faith based representative organizations, Faith based charitable or development organizations, Faith based socio political organizations, Faith based missionary organizations and Faith based radical, illegal or terrorist organizations.

Clarke and Jennings (2008, p. 6) proposed the definition of FBOs as 'any organization that derives inspiration and guidance for its activities from the teaching and principles of the faith or from a particular interpretation or school of thought within the faith'. This is an inclusive definition which covers charity organizations to NGOs that seeks inspiration from faith.

Clarke and Ware (2015) proposed four types of FBOs: FBOs directly linked to local congregation or religious leader, FBOs directly linked to a religious denomination/sect and are formally incorporated within the institutional organization of the religious body, FBOS linked to a religious denomination/ sect but are incorporated separately from that religious body. 
Finally FBOs that identify themselves as falling within a broad religious tradition from which they draw motivation (Clarke \& Ware, 2015, p. 40).

Clarke and Ware (2015, pp. 40-44) compared between FBOs and NGOs and found six types of FBOs; intersectional sharing few common organizational features, distinct in nature, substitive (sic) sharing common goals, similar kind of organizational features but different on the basis of faith, FBOs as a subset of NGOs where only NGO-like registered FBOs can accommodate, co-existing which are distinct in nature but works with NGOs in civil society and atomistic FBOs having many individuals and distinct organizations that have many differences but have a common faith based premise apart from these six models, they proposed a new model to understand FBOs named constitutive model where FBOs work as a center connecting with four bodies; Communities, Religious Organizations, NGO and Civil Society (Clarke and Ware, 2015, p. 45).

DFID (2012, p. 3) also tried to incorporate different kinds of faith groups as FBOs.

a. Congregational faith groups of believers predominantly focused on worship;

b. Representative faith organizations both nationally such as Network of Sikh Organizations UK and internationally such as the World Council of Churches;

c. Faith-based development organizations that focus on international development such as World Vision and Islamic Relief;

d. Faith-based political organizations such as the Christian Democratic Union in Germany; e. Faith-based missionary organizations promoting their faith;

f. Inter faith groups working with other faiths and to build understanding such as Religions for Peace;

g. Other organizations in which faith plays an important role such as the 'Guides' and 'Boys Brigade'.

From the above discussion, FBOs can be divided into two broad categories; formal and informal.

Formal FBOs are more organized and have a systematic structure to function their activities. There are many Faith based Organizations that seem more like NGO. They are registered as NGOs in different countries. Because of organizational nature, faith based political parties can be incorporated in this category. They may be local, and international as well. Though they seek inspiration from Faiths, they usually don't differentiate people in service provision. On the other hand, informal FBOs cover mainly churches, mosques and temples which can be regarded as a unit station for every faith based service provision. Though these FBOs are not organized or structured like formal FBOs, structured FBOs sometimes rely on these local churches, mosques or temples for establishing network in the local areas. Though these two categories are distinct only in organizational capacity, they have a unified goal to provide service to the people and to ensure development.

In this article, three concerning issues are going to be discussed. These are sectarian service provision, conversion and terrorist financing.

\section{Sectarian Service Provision}

A society can be divided in various ways. Flanigan (2010) developed a theory arguing that a conflict prone society is more 
divided. Divisional elements like ethnicity, religion and race accelerate these segregations among people. These elements also influence the behavior of the members of different Faith Based Organizations. Local Faith Based Organizations are affected and influenced more by this societal division in compare to the international Faith Based Organizations (Flanigan, 2010, p. 6). She considered Power as a major factor in the relationship between the FBOs and the recipients. Reception of service is largely based on the power dynamics between a recipient and a FBO. If a recipient is powerful, he or she might get a more chance to get service from FBOs. This power disadvantage has two aspects; FBOs can exclude members of other faiths to receive services and sometimes the poor avoid specific service sectors. This exclusion in turn helps to keep a section of people beyond receiving services (Ibid., 7).

Flanigan (2010) analyzed few case studies from Lebanon and found that sectarian service provision is persistent there. During the civil war (1975-90), religious identity became the major identifier of the people as the country was struggling in civil war as a means of collective violence. They were segregated in numerous divisions like the Sunni Muslims, the Shiites Muslims, the Christians, the Palestinian Muslims and the Druze. During this time, due to the poor government service provision, one of the largest voluntary sectors including Faith Based Organizations was grown in Lebanon (Ibid., 19).

Faith based organizations have been playing a major role in Lebanon. According to the respondents of Flanigan (2010), they are more caring, more compassionate, more credible in the society, more committed and more suited even in war prone zone. The FBOs staff members usually choose to work in FBOs for their personal tie with a religion though many Druze
FBO members told that they sought inspiration from humanism instead of faith (Ibid., 28-36).

Flanigan (2010) in her study argued that non-government service provision including different FBOs is clearly structured with sectarian lines. FBOs are often seen to serve a specific community. A FBO can be seen serving a ethnic race according to its ethnic origin. But Christian international FBOs are exception in this regards Ibid., 37). Religious sects are politically significant also. Thus, every religious sect belongs to different power house. According to the study of Flanigan (2010), service reception also depends on the power structure. The powerful sects get more service. This power structure is deeply influenced by religious ideology in Lebanon. Political groups have roots in religious sects. For instance, Hezbollah is a political group which is based on Shiites sect. They have a powerful domination in Lebanese politics. Hezbollah funded Shiites FBOs that mainly focus where most of the people are Shiites.

In an interview with Flanigan (2010), a staff member of Muslim a FBO said: "It's not in our rules and regulations to accept only Muslim children but we have to be realistic, i.e. mean, this is Lebanon. Lebanon is divided. We don't reject any child based on religion, but this is the situation everywhere. If you go to the Druze NGOs, you will that the majority are Druze... So, to the Shiites NGOs and Xian NGOs" (Ibid., 38).

The question arises do these FBOs reject other Faith members if they seek service from them? According to the respondents of Flanigan, Faith is not the official criterion to get service from the FBOs. Poverty is the only criteria (Ibid., 39). If that is the case in reality, then why do FBOS act like 
sectarian? The study of Flanigan (2010) also reveals that this is because of practical reasons. Usually in Lebanon, the service seekers from FBO belong to the same faith and with the limited resources what local FBOs have cannot be possible to serve all. But they don't reject anyone who seeks services from them (Ibid., 39). That is why Flanigan (2010) concluded that FBOs in Lebanon are thus inclusive in theory and sectarian in practice.

The sectarian nature of service provision in Lebanon is not only because of faith but also for geographical divisions. This geographical segregation is responsible for sectarian service provision for the secular NGOs. Members of these local secular NGOs are sometimes recruited based on region. That is why a sectarian service provision becomes an automatic result in these areas (Ibid., 50).

This case study cannot be generalized in everywhere. Because this theory can only be applied where there are extreme divisions among the people on the basis of religion, geographical boundaries and ethnicity. Most importantly, international FBOs are the least sectarian in service provision even working in a divided area. International FBOs World Vision or Islamic Relief for instance do not differentiate among the recipients of services. So, it is erroneous to apply sectarian tag for all FBOs.

\section{Conversion}

Allegations of proselytization or conversion against missionary churches are a very old criticism. Sometimes these allegations have been made from pre-judgmental stand point, sometimes from facts, sometimes from generalizations and sometimes only for being foreign religion (not has a historical root in a country from distant past). It's is undeniable that evangelical churches have a goal to attain more adherents and to expand their religion. Missionary conversion is not a new phenomenon. Fountain (2015) described Proselytization as the 'prickliest subject' of religion and development discourse. Secular development practitioners regard conversion illegal and dangerous. That is why they have been working to separate proselytization from humanitarian development. They consider proselytization as a threat that breaks the core demarcation line between religion and development (Fountain, 2015, pp. 80-84). But Benthall and Bellion-Jourdan (2009) argued that Christian missionary activity and missionary aid have been progressively de-linked from each other since the beginning of the Red Cross Movement (Benthall and Bellion-Jourdan, 2009, p. 159). Since the movement started, aid or humanitarian development was not directed towards specific group of people belong to that religion. In many countries like Sri Lanka, Pakistan, Bangladesh, India and many others, conversion is viewed as a negative task. If church has a predetermined stand point to expand Christianity or evangelism, then it is not different from the religious expansion teachings of Islam. But why do church faces criticism for conversion? A critical analysis is a demand to understand whether church compels any specific section of people to accept Christianity or church provokes the poor in exchange of material benefits?

After the devastation of Tsunami in Sri Lanka, a huge number of Faith based organizations emerged in Sri Lanka. But unlike Lebanon or many African countries, these Faith Based Organizations were unwelcomed by both people and government. In the meantime, Non-Government Organizations 
have had a negative image in Sri Lanka as many NGOs were charged of interfering internal politics of Sri Lanka and assisting the LTTE Tamil (A rebel group sought liberation who were mainly Hindu and Tamil in ethnic race, led by Venu Pillai Probhakaran). A new fear emerged in the Sri Lankan people that FBOS especially international FBOs might have been working for converting Sri Lankans of all religious groups to an evangelic Protestantism (Flanigan, 2010, pp. 65-72).

Especially evangelic FBOs were alleged with conversion. To ban conversion, a parliament member brought a bill against conversion affirming that conversion in exchange of any allurement will be illegal. This allurement was defined as "any temptation in the form of: 1 . Any gift or gratification whether in cash or kind; 2. Grant of any material benefit, whether monetary or otherwise; 3 . Grant of employment or grant of promotion in employment" (Ibid., 73).

This bill is too generalized and does not depict a perfect picture of the relationship between many faith Based Organizations and this law of conversion. Under this law, it is impossible to work in charity or to provide service to the poor while the term 'allurement' covers every work of service provision. This law can hardly differentiate the charitable or development work of FBOs and active conversion allurement. In response to this allegation, the National Christian Council said that humanitarian work is innate in every religion and it was not true to label against them.

In 2004, Asma Jahangir, especial rapporteur to the United Nations visited Sri Lanka and she admitted that there were few incidents of conversions. But she did not find any example of direct or forceful conversion (Ibid., 73). But Asma Jahangir did not connect her conclusion with conversion due to any allurement or in exchange of any material exchange.

Based on the influence of the faith groups on people, conversion can be divided in three categories; active, passive, forceful. When a religious group has the target to attain more adherents and thus works to promote their religion, this is called active conversion. This work includes preaching religion, charitable social service provision and allurement in some cases. On the other hand, when a religious group works for society which has practical implications on the poor, then people can be attracted towards the teachings of those religions and can embrace new religions. Religious motivation is there but it is not active. This group does not primarily focus on conversion. Conversion, for them can be the result of their humanitarian works. When people especially from minority groups are bound to accept the religion of the majority, this is called forceful conversion. Forceful conversion mainly includes threatening.

Conversion can also be divided in two categories based on providing material benefit; conversion by choice and conversion by chance. For instance, ' $\mathrm{A}$ ' is a FBO that aims to work in human development. This FBO has been working in country ' $\mathrm{F}$ ' for 5 years. In this region, most of the people are poor and they have been affected by many epidemics, flood and civil war. Staff members who belong to religion ' $C$ ' do not preach their religion actively. Instead they preach that they got the inspiration from the religion to work for the humanity. Under this FBO, a lot of poor people get their daily food and medicine. As government assistance is rare, this FBO is the main hope of these poor people. This FBO established school teaches secular education and religious as well. The recipients 
of this education can be attracted to the teachings of this religion. This is a case of passive conversion. On the other hand, poor people who are the continuous recipients of the service of the given FBO can also accept the Faith of the FBO. In this given circumstances, if anyone converts his/her religion, this is religion by choice. Here, conversion cannot and should not be branded as negatively. They preach their teachings and if people want, they can accept another faith.

Another case study from Hovland (2008) can give more clear picture of this issue. Hovland (2008) has analyzed the complex relationship between evangelism (conversion) and development programs of Norwegian Mission Society (NMS). NMS is funded by the Norwegian Agency for Development Cooperation (NORAD) for development purposes. That is why, NMS has two categories of organizational budget; one is development budget and the other one is mission budget. NMC policy stand for a clear separation between mission and development for three reasons; they encourage the organizational members through three 'new work' programs including evangelism, development and capacity building, they wanted to project themselves as a good organization having clearly defined programs and the accountability to NORAD regarding the spending of the fund. The staffs are called 'missionaries' and they are taught to keep development activities separated from evangelism (Hovland, 2008, p. 173). NMS which was founded in 1842 recruits staff members form Christianity. NMC believes Christianity as a true faith and actively try to convert non-Christian to the same Christian belief. They spend their budget in three ways; a. conversion of the non-Christian, b. development works in developing countries which is mainly in service sectors like education, health, agriculture and water, c. capacity development of the churches (Ibid., 174). Despite official division between two aspects of NMS, critics claim that this division is not in practice and the result of NMS work was a dangerous convergence of mission and development. They were accused of paying staff salary form NORAD fund which was prohibited by NORAD law and official rules of NMC as well (Ibid., 173).

Hovland (2008) in his research found that NMS does not promote conversion in exchange of any material goods. The NMS conversion policy is grounded in Lutheran teachings where conversion in exchange of any material goods is not considered as pure conversion. From a distant past, NMC members have been keeping development and conversion separate. Even the missionaries of NMC emphasizes the practical development programs like agriculture and education (Ibid., pp. 175-176). Faith based Organizations receive 12 million pounds from NORAD for development activities. But this fund is given to them with prior assumptions that FBOs will spend the given amount of money only in development purposes. This was highly criticized in Norway as Norway has always been known as highly secularized country where religion is kept only as a personal matter. Hovland (2008) cited Terje Tvedt (n.d.), a development academic as follows:

"What would be the starting (Norwegian Parliament) say if the Indonesian or Saudi Arabian state funded fundamentalist Muslim organizations that carried out charity work among street children in Oslo, but primarily were concerned with Islamizing all of Norwegian society?" (Ibid., p.177).

This argument illustrates that a FBO which aims at proselytization or conversion cannot keep their faith passive in development activities. Through their activities they will try to 
provoke people to accept their faith. According to NORAD policy, NMS keeps conversion and development separated. But as NMS mainly aims at attaining more adherents, therefore chances of proselytization is high.

In his research, Hovland (2008) concluded that NMS try their best to keep the two distinct things separate. But he did not answer the question when he found his respondents (missionaries of NMS) telling him about the conversion in exchange of benefits. If a group of people get services like health, education, agriculture then there is a good chance of conversion especially in African countries. Hastings (1994) argued that the Africans did not pay any heed to the biblical messages. The British empire tried to spread the message of Christianity but failed. Then they offered the Africans education, food, agricultural commodities, health services and employment opportunities. This service provision strategy brought a great success for the British to spread Christianity in Africa. The principal weapon was material benefit instead of spirituality (Hastings, 1994, p. 274 as citied in: Denuelin and Bano, 2009, p. 70). For instance, Bornstein found that World Vision, one of the leading evangelic development organizations actively proselytize people of Zimbabwe. Every staff member is bound to sign up in a faith statement paper. In every project site, evangelism committee are also established there. This experience of Zimbabwe thus reveals that evangelical development has also direct aim of converting people (Bornstein, 2002, as cited in: Clarke, 2007, p. 83).

According to one of the respondents of Hovland, a traditional belief persists in Africa that conversion to Christianity will ensure a better future. That is why a significant number of poor are being converted to Christianity for a better future. Hovland (2008) though analyzed that this view is not applicable to all missionaries and this is against the ideology of NMS. Here, if the criticism of Tvedt is considered then this can be examined in a broader way. The priority policy of NMS is to attain new converts. When they work in a community for development purposes and providing services they do not keep their faith aside. Thus, an indirect influence will be there on the service recipients. It is difficult to make faith and development separate.

\section{Terrorist Financing}

Terrorist financing through FBOs is one of the burning issues in the development world. According to Anand (2009), the term 'terrorist financing' can be applied to two activities. One is fundraising activities by which a terrorist organization patronizes its all activities including arms buying, spreading propaganda, strengthening organizational capacity and training for the recruits. The other is implementing specific terrorist operation like suicide bombing, target killing and others (Anand, 2009, p. 903).

Burr and Collins (2006) argued that the number of the Islamic Charities or FBOs associated with terrorist financing is not many, but these FBOs are very significant with a widespread connection of terrorist groups. For example, in 2004, there were only 14 international Islamic Charities who were proved to keep ties with Al Qaida (Burr and Collins, 2006, pp. 1-2). Though this number was increased later.

Bangladesh has been fighting against terrorism for few decades and different terrorist groups surfaced in Bangladesh for years (Islam and Siddika 2020, Islam and Huda 2016, Islam 2020). Islamic charities in Bangladesh in few cases have been 
accused of a connection with terrorist financing. For instance, the Society of the Revival of Islamic Heritage, who rely on the donations from the Middle East has been accused of terrorist financing in Bangladesh (Adams, 2016, p. 61). They have been accused of keeping ties with some Islamic extremist groups like Jagrata Muslim Janata Bangladesh (JMJB), Jamaatul Mujahideen Bangladesh (JMB), Al Hikma, Harkat-ul-Jihad (HuJi), Ansarullah bangla Team (Anand, 2009, p. 904). The government has, in the last few years, banned these groups. Apart from these known local groups, all terrorist groups designated as such by the UN Security Council Committee have also been banned (CRI, 2016, p. 4).

It is difficult to get the exact statistics of the funds arriving in Bangladesh in NGO sector. But it is estimated by the government officials that it is about 61.5 million to 76.9 million US dollars per year. There are about 575 registered Islamic Faith Based Organizations are now active all over the country with foreign funds coming from Libya, UAE, Qatar, Kuwait, Iran, Egypt, Pakistan, Iran, USA and UK. But only thirty-five organizations are broad in networking and activities. These are known as mother organizations (The people's Daily, 2005).

Cochrane (2009) considers Bangladesh is one of the key ways of illegal financial transfers through Faith Based Organizations. NGOs or Faith Based Organizations have been a key source of militant funding as international terrorist organizations often use these FBOs to send money to their local agents. The Saudi Arabia-based al- Haramain Islamic Foundation, which is banned throughout the world by United Nations Security Council Committee 1267, and many other FBOs like the Kuwait-based Revival of Islamic Heritage
Society (RIHS), Hayatul Igachha (HI) have been accused of funding terrorist organizations like jamatul Mujahidin Bangladesh, Ahle Hadis Andolon in Bangladesh (Cochrane, 2009, p. 2).

Cochrane (2009) writes that mainstream political parties like Jamat e islami Bangladesh (JIB), Islami Oikkojot have been accused of keeping ties with extremists. Many of the top leaders of different extremist parties like Shaikh Abdur Rahman, Bangla Bhai were activists of Jamat e islami Bangladesh JIB. The NGO bureau is also concerned regarding many of the Faith Based Organizations, more especially Islamic Charities that have link with these groups. During 2001 to 2006 , the ministry of social welfare was headed by Ali Ahsan Mujahid, the then Secretary General of Jamat e islami Bangladesh (JIB). This time was the apex for the increase of the numbers of NGOs including 475 local and 25 international NGOs (Cochrane, 2009, p. 3).

This is undeniable that in Bangladesh, Faith Based Organizations have a deep rooted development contribution. Islamic education in Bangladesh has been promoted and funded by many foreign Faith based organizations and governments. But Bhattacharjee (2016) found a constant concern which has been noticed due to the continuous ties between many of the Saudi based FBOs and local terrorist organizations. They also fund for the promotion of Saudi patronized ideology 'wahabism'. For example, Al-Haramin Islamic Foundation, a world-wide banned organization by UN security was found having relation with al Qaida. They set up an office at Dhaka and opened bank account Al Arafah Islami Bank in Dhaka. But after a bomb blast in Saudi Arabia, Saudi government requested Dhaka to freeze the bank account of Al- 
Haramin. Bangladesh government started a thorough investigation. The central bank of Bangladesh found that a huge amount of money which was untraced was released to persons from its Cox's bazar and Rangpur branches. RIHS (funded by Kwait) and Hayatul Igacha (funded by Saudi Arabia) were aiding more than six hundred mosques throughout the country. Radical extremist parties like Ahle Hadith Andolan Bangladesh and JMB-affiliated Jagrata Muslim Janata Bangladesh used many of these mosques for their purposes (Bhattacharjee, 2016, pp. 3-4).

After the serial bomb blast in Bangladesh on 17 August, 2005 in 63 districts of, the security agencies of Bangladesh started to revision the role of Islamic FBOs in Bangladesh and their so-called ties with the terrorist organizations. After the critical scrutiny, at least ten FBOs were found to have a close tie with some terrorist organizations. This was the Revival of Islamic Heritage Society (RIHS), Rabita Al-Alam Al-Islami, Society of Social Reforms, Qatar Charitable Society, AlMuntada Al-Islami, Islamic Relief Agency, Al-Forkan Foundation, International Relief Organization, Kuwait Joint Relief Committee, and Muslim Aid Bangladesh. Many of the FBO workers came to Bangladesh with a tourist visa and stayed afterwards as illegal residents. They were mainly from West African countries. According to the intelligence report, Ahle Hadis Bangladesh, a Saudi based Islamic sect who spread Wahhabi teachings (headed by Asadullah Galib) received funding from RIHS and other Saudi organizations. Galib was arrested for extremist activities in Bangladesh including attack on the NGO offices and cultural programs in many places of Bangladesh. United States banned the RIHS because of its tie with Al Qaida. Asadullah Galib confessed that he used the RIHS fund for different operations of the JMB, purchased weapons and trained recruited followers. He received around 2.7 million pound every year which was channeled from the middle east (Ramcharan, The Asia Times, 22 September, 2005).

Ramcharan (2005) argued that it is wrong to accuse all FBO channeled money funding the terrorists. Money is mainly sent for religious works, spreading religious education, working for orphans, erection of mosques and madrasas (religious education centers). But a portion of money of few FBOs are spent for extremists' purposes including funding terrorist operations, training the followers and spending money for the poor to allure themselves

After the series bomb blast in 63 districts, at least five RIHS officials had to leave Bangladesh. They also worked for Al Haramain in Bangladesh who has a close tie with Al Qaida. In 2009, a UK based Islamic FBO Green Crescent was brought under scrutiny for spreading extremist teachings through madrasas (Manik, 2009). After the arrest of Galib and Samad Salafi, the government frozen the funds of RIHS. But surprisingly later on this fund was released and distributed to many contractors by bearer cheque. In November, 2005 this RIHS has been accused of bombing on two court premises (The Daily Star, December 05, 2005).

It is said that the total number of FBOs associated with terror funding is obscure, but this number is limited. In Bangladesh, FBOs are being used as a channel of terrorist financing. But this statement is too generalized and may project a negative picture on the FBOs who are working in many development sectors in Bangladesh. This generalization may 
lead the donors to avoid funding all Islamic FBOs. Because of only a few FBOs associated with terrorists, all FBOs must not be judged equally. In this case, a critical scrutiny is a demand from the government to ban these outfits and give the FBOs full status as development partners. Over the last few years, country like Bangladesh has demonstrated a considerable measures to check terrorist financing. But more robust measures must be needed in near future in the age of super-fast technological age.

\section{Conclusion}

Faith Based Organizations have a great development impact in the world. Secular development strategists are also admitting the role of the faith Based Organizations. The nexus between the FBOs with the secular development model has brought a significant change in the development field. The contribution of the FBOs in any form whether charity organization or the faith based NGOs have been visible in various sectors like education, health, democratization, climate change, poverty reduction program, conflict resolution and many other development sectors. At the same time, at least three criticism have been focused against the Faith Based Organizations; sectarian service provision, conversion and terrorist financing. These criticisms are true in many cases. But the criticisms are too generalized and can depict a wrong picture about the role of the FBOs in development field. Sectarian service provision can be seen mainly in conflict prone zone by the local FBOs. International FBOs always try to accommodate all people belonging to different faiths. This segregated service provision is accelerated by the argument that when a region is at conflicting situation, people may have more belief on the FBOs who belong to their local religion. On the other hand, conversion is a common criticism against the missionaries. Though in many places, conversion took place in exchange of material benefit, it cannot be said that all missionaries did the same. In the present day 'development world', the missionary churches or Christian FBOs have divided their works in two section; development work and religious work. Though secular development practitioners still express their doubt that, to what extent Christian FBOs could keep themselves apart from converting people. Finally, Islamic FBOs are criticized with terror funding. Some middle eastern countries mainly maintain the link with the Islamic FBOs who provide fund to the terrorist groups. This criticism is also too narrow indeed. Only a few international FBOs have a connection with the terrorist but this small number has a significant influence in terrorist networks. Sometimes state monitored FBOs from middle eastern countries are financing the terrorists. Thus, a negative picture has been projected to the world about the Islamic FBOs which is itself a negative branding for all kinds of FBOs. This criticism may damage the image of the FBOs and can underestimate their development impact. That is why, it is high time to bring this terror funding FBOs under critical supervision. The missionaries must keep themselves apart from forceful conversion or conversion in exchange of any material benefit. Development works should not be used as tool to increase the adherents. Though sectarian provision is not applicable to all, this sectarian nature can be reduced significantly by keeping the door open of all FBOs for all people belonging to different religions. 


\section{Bibliography}

Adamds, N. (2015). Faith and Development in Focus: Bangladesh. USA: Berkley Center for religion, Peace, and World Affairs, Georgetown University.

Burr, J.M. and Collins, O. (2006). Alms for Jihad: Charity and Terrorism in the Islamic World. Cambridge: Cambridge University Press.

Benthall and Bellion-Jourdan. (2009). The Charitable crescent: The politics of Aid in the Muslim World. London: I.B. Tauris and Co Ltd.

CRI. (2015), Combating Terrorism ensuring peace. Dhaka: Center for Research and Information.

Clarke, G. (2008). Faith Based Organizations and International Development: An overview. In: Clarke, G. and Jennings, M. ed. Development, Civil Society and faith Based Organizations: Bridging the sacred and the Secular. London: Palgrave Macmillan. pp. 17-45.

Clarke, G. (2007). Agents of Transformation: Donors, faith-Based Organizations and International Development. Third World Quarterly. 28(1), pp. 77-96.

Clarke, M. and Ware, V. (2015). Understanding faith based organizations: How FBOs are contrasted to NGOs in international development literature. Progress in Development Studies. 15(1). pp. 37-48.

DFID. (2012). Faith Partnership Principles: working effectively with groups to fight global poverty. [Last accessed 22 January, 2017]. Available at http://www.espncricinfo.com/magazine/ content/story/1078485.html

Denulin, S. and Bano, M. (2009). Religion in Development: Rewriting the Secular Script. London: Zed Books.
Flanigan, S.T. (2010). For the Love of God: NGOs and Religious Identity in a Violent World. USA: Kumarian Press.

Fountain, P. (2015). Proselytizing Development. In: Tomalin, E. ed. The Routledge Handbook of Religions and Global Development. London: Routledge. pp. 80-98.

Haynes, J. (2007). Religion and Development: Conflict or Cooperation. London: Palgrave Macmillan.

Hovland. (2008). Who's Afraid Of religion? Tensions between 'Mission' and Development' in the Norwegian Mission society. In: Clarke, G. and Jennings, m. ed. Development, Civil Society and faith Based Organizations: Bridging the sacred and the Secular. London: Palgrave Macmillan. pp. 171-186.

Islam, M. D. (2019). De-radicalisation of Terrorists: Theoretical Analysis and Case Studies. Counter Terrorist Trends and Analyses, 11(5), 6-12.

Islam, M.D and Siddika, A. (2020). Exploring the causes of religious extremism in Bangladesh: a critical analysis. The Dhaka University Studies. July 2015-June 2017.

Islam, M.D. and Huda, Fazrin. (2016). Religion and Politics: Bangladesh Perspective. International Journal of Management and Humanities (IJMH). 2(4). pp. 1-5.

Islam, M.D. (2020). Understanding secularisation as indicating the process of the separation of the political and religious. The Arts Faculty Journal. 10 (14-15).

Islam, M.D. (2020). Religious freedom for the religious minorities in Bangladesh: A critical analysis of the insertion of state religion in the constitution. DOI: 10.13140/RG.2.2.12426.41925

Kothari, CR. And Garg. (2015). Research Methodology. India: New Age International

Kumar, A. (2009). Terror Financing in Bangladesh. Strategic Analysis. 33(6). pp.903-917. DOI:10.1080/09700160903255913 
Manik, J.A. (2009). Green crescent ran illegally. The Daily Star, April 1, [last accessed January 15, 2016]. http://www.the dailystar. net/news-detail-82229

Occhipinti, L.A. (2015). Faith-based Organizations and Development. In: Tomalin, E. ed. The Routledge Handbook of Religions and Global Development. London: Routledge. pp. 331-345.

Ramachandran, S. 2005. Mixing aid with terror, The Asia Times. 22 September. [last accessed 15 January 2017]. available at http:// www.atimes.com/atimes/South_Asia/GI22Df01.html

Siddika, A. (2021). Religion and Development: Assessing the Contribution of the Faith Based Organizations in Bangladesh. International Journal of Management and Humanities (IJMH). $5(5)$.

The Daily Star. (2016). December 05. Govt okays release of fund to 'terror funder'. [last accessed January 15, 2017]. Available at http://archive.thedailystar.net/2005/12/05/d5120501044.htm.

Tomalin, E. (2013). Religions and Development. London: Routledge.

The people's Daily. (2005). September 6. [last accessed 16 January, 2017]. Available at http://en.people.cn/200509/06/eng20050906 206886.html.

N.B. This article was primarily produced as a partial fulfilment of my MA in Religious studies and Global Development at the University of Leeds (2017). Later, it was redrafted as a journal article. 